\title{
Reproductive Performance Of Bali Cattle Cross Breed Brahman Cattle Through Improving The Genetic Quality Of Local Livestock In Special Effort for Cows to be Pregnant Program
}

\author{
Irwansyah $^{1}$, Junaedi $^{1 *}$, Suparman $^{1}$ \\ ${ }^{1}$ Department of Animal Husbandry, Faculty of Agriculture, Fisheries and Animal Husbandry, Universitas Sembilanbelas \\ November Kolaka. Jl. Pemuda No. 339, Kolaka 93517, Southeast Sulawesi, Indonesia \\ *junaedi.peternakan@gmail.com
}

\begin{abstract}
ARTICLE INFO
Article history

Received 12 June

2021

Received in revised

from 23 June 2021

Accepted 24 June

2021

Available online.

24 June 2021

Key words:

Performance;

Reproduction;

Bali Cattle;

Cross Breed.

ABSTRACT

One of the problems that exist in the community is the lack of identification of the reproductive performance of prospective brooders of Bali cattle that are artificially inseminated. The researcher conducted a research to determine the reproductive performance of Bali Cattle inseminated with Brahman Cattle Semen in SECP (Special Effort for Cows to be Pregnant Program) Program in Kolaka Regency. The parameters observed in this study were; artificial insemination's first age (Years), How many times the artificial insemination (AI) was pregnant (S/C), Length of pregnancy (months), Calving Interval (CI) (months), Birth weight (Kilograms), Correlation of AI's first age with birth weight. Sources of date used in this study are primary and secondary data. Data collection techniques carried out in this study were observation and interviews. The date obtained was analyzed descriptively, analysis of variance, average, and to calculate the relationship between variables was analyzed by correlation. Reproductive performance of Bali Cattle inseminated with Brahman Cattle Semen in SECP Program in Kolaka district include; first age AI 23.63 \pm 1.99 months, Service per Conception (S/C) 1.56 \pm 0.55 , gestational age $9.03 \pm 0.38$ months, Calving Interval (CI) 12.24 \pm 0.52 months, birth weight $27.85 \pm$ 2.96 and the correlation between AI prime age and birth spacing was 0.77 .
\end{abstract}

\section{INTRODUCTION}

Food products of animal origin as one of the most basic needs, the food needs to get attention from the aspect of availability (Syakir, 2015). Food is the most important basic need in fulfilling the human rights of every individual (Suryana and Munawar, 2017). Foodstuffs from livestock such as meat, eggs and milk are easily contaminated by microorganisms which cause food from livestock to be easily damaged (Lestariningsih et al., 2019). Beef is one of the sources of animal protein that is in great demand by people in Indonesia. According to Adawiyah et al. (2016) that, the factors that determine the level of animal food consumption in Indonesian society are increasing, because people's purchasing power of beef is quite high. The need for beef is quite high, so the market opportunities for beef and beef cattle are increasing, so that small farmers, large entrepreneurs and clothing can take advantage of these opportunities (Direktorat Jenderal Peternakan dan Kesehatan Hewan, 2017).

The development of the livestock sub-sector in Indonesia, especially Southeast Sulawesi, needs to be improved. This is 
because the need for livestock products tends to increase from year to year in line with the increasing awareness of the nutritional needs of the community. However, the increase in demand is not balanced with the increase in livestock population. Southeast Sulawesi is one of the centers for livestock development that has potential natural resources for beef cattle because it has a relatively large area of land. Badan Pusat Statistik Kabupaten Kolaka (2020), the distribution of cattle population in Southeast Sulawesi in 2020 covers seventeen city districts with a total of 419,882 heads.

Special Effort for Cows to be Pregnant Program (SECP) is one of the government's efforts to accelerate the increase in the population of beef cattle sustainability. The scope of SECP activities includes handling reproductive disorders, AI and natural mating services, controlling the slaughter of productive female cattle and fulfilling forage and concentrate fodder.

The government at the end of 2016 has launched the Mandatory Pregnant Cattle Program (SIWAB). This program is supported by the Regulation of the Minister of Agriculture of the Republic of Indonesia Number 48/Permentan/PK. 210/10/2016 concerning Special Efforts to Accelerate the Increase of Pregnant Cattle and Buffalo Populations. The problem to be solved with this program is to increase meat production to balance between supply and demand in the country which is currently increasing. According to Direktorat Jenderal Peternakan dan Kesehatan Hewan (2017), SECP is an integrated activity to accelerate the increase in cattle population in a sustainable manner. The government's program of increasing the beef cattle population is to reduce the slaughter of productive female cattle and expand the range of crossbreeding programs for local female cattle with artificial insemination (AI). Improvements in AI activities in Indonesia are currently being carried out and will continue to improve livestock population, quality and production.

One of the efforts that can be taken to increase the production of meat and calves is to improve the genetic quality of livestock with the SECP program with Artificial Insemination (AI). One of the problems that exist in the community is the lack of identification of the reproductive performance of prospective breeders of Bali cattle that will be artificially inseminated in the SECP program. In addition, the male semen used by inseminators in Kolaka district generally uses Brahman cattle, so that the provision of superior broodstock for Bali cattle needs to be considered. Based on this background, the researchers conducted research to determine the reproductive performance of Bali cattle inseminated with Brahman cattle semen in the SECP Program in Kolaka district.

\section{RESEARCH AND METHODS}

\section{Research Location and Time}

This research was conducted in Watubangga, Toari and Tanggetada Districts, Kolaka Regency, Southeast Sulawesi, from February to June 2021.

\section{Population and Sample}

The population in this study was taken by sampling, namely farmers who participated in the SECP program. The number of samples was taken by purposive sampling as many as 70 respondents, farmers who have at least one female cattle who participated in the SECP program.

\section{Observed Parameters}

The parameters observed in this study were:

1. IB's first age (years)

2. How many times did the new AI get pregnant $(\mathrm{S} / \mathrm{C})$

3. Length of pregnancy (months)

4. Calving Interval (CI) (month) 5. Birth weight (Kilograms) 
6. Correlation of AI Prime Age with Birth Weight

\section{Date Type and Retrieval}

Sources of the date used in this study are primary and secondary date. The primary date were obtained from questionnaires given to breeders regarding the implementation of AI, age at first AI, number of new AI's pregnant $(\mathrm{S} / \mathrm{C})$, duration of pregnancy, Calving interval (CI). The secondary date is obtained from the AI card or the results of the recording of AI implementation by livestock officers and inseminators of Kolaka Regency.

\section{Date Collection Technique}

The date collection techniques used in this study are:

1. Observation, namely direct observation at the research site, in these case cattle farmers who received Artificial Insemination (AI) technology services in Kolaka Regency.

2. Interview, namely collecting date by conducting direct interviews with cattle farmers who received Artificial Insemination (AI) technology services. To facilitate the interview process, a questionnaire or a list of questions that have been prepared according to research needs is used.

\section{Date analysis}

The date obtained was analyzed descriptively, analysis of variance, average, and to calculate the relationship between variables was analyzed by correlation. The close relationship between variables can be seen from the magnitude of the correlation coefficient (r). To calculate the correlation coefficient using the formula (Gomez and Gomez, 2007):

$$
r=\frac{n \Sigma X Y-\Sigma X \Sigma Y}{\sqrt{\left[n \Sigma \mathrm{X}^{2}-(\Sigma X)^{2}\right]\left[n \Sigma Y^{2}-(\Sigma Y)^{2}\right.}}
$$

$\mathrm{r}$ : Correlation between variable $\mathrm{x}$ and variable $\mathrm{y}$

$\mathrm{n}$ : number of samples

$\mathrm{x}$ : Value of variable $\mathrm{x}$

$\mathrm{y}$ : Value of variable $\mathrm{y}$

The magnitude of the correlation coefficient ranges from +1 to -1 . The correlation coefficient shows the strength (strength) of a linear relationship and the direction of the relationship between two random variables. If the correlation coefficient is positive, then the two variables have a unidirectional relationship. This means that if the value of the variable $X$ is high, then the value of the variable $\mathrm{Y}$ will be high as well. Conversely, if the correlation coefficient is negative, then the two variables have an inverse relationship. This means that if the value of $\mathrm{X}$ is high, then the value of the variable $\mathrm{Y}$ will be low (and vice versa). To make it easier to interpret the strength of the relationship between the two variables, the authors provide the following criteria;
a. 0 : There is no correlation between the two variables
b. $>0-0.25$ : Very weak correlation
c. $>0.25-0.5$ : Correlation is sufficient
d. $>0.5-0.75$ : Strong correlation
e. $>0.75-0.99$ : Very strong correlation
f. 1: Perfect correlation

\section{RESULT AND DISCUSSION}

The success rate of reproductive performance of the AI program with Bali cattle and Brahman bulls in this study was assessed from the number of AI's first age, Service per Conception (S/C), length of pregnancy, Calving Interval $(\mathrm{CI})$, birth weight and the correlation between AI's prime age and 
Table 1. Reproductive Performance of Bali Cattle Inseminated with Brahman Cattle Semen in SECP Program in Kolaka Regency

\begin{tabular}{lc}
\hline Observed Parameters & Averages \\
\hline AI's first age (month) & $23.63 \pm 1.99$ \\
Service per Conception (S/C) & $1.56 \pm 0.55$ \\
length of pregnancy (month) & $9.03 \pm 0.38$ \\
Calving Interval (CI) (month) & $12.24 \pm 0.52$ \\
birth weight (kg) & $27.85 \pm 2.96$ \\
the correlation between IB's first age and birth weight & 0.77 \\
\hline
\end{tabular}

age. Birth Distance. The research parameters can be seen in Table 1.

\section{AI's First Age}

Bali cattles were first inseminated with Brahman cattle semen in this study at the age of $23.63 \pm 1.99$ months. This is in accordance with the opinion of Handiwirawan and Subandriyo (2007) which states that the age at first mating female cattles is 18-24 months. The age at which animals are first mated has two implications. Mating at a young age can shorten the generation interval, thereby increasing the degree of selection response to certain genetic traits. The faster the cattle are mated, the faster the livestock can produce so that the livestock business is more economical. Under certain conditions, the mating of females is deliberately postponed with the intention that the cattle do not give birth too small to avoid the occurrence of dystocia (Lindsay et al., 1982). The age and body size of the heifer at the time of first mating need attention, so that a high conception rate is obtained and prevents difficulty in calving. Heifers that are not bred until they exceed the age and body size that should have been bred the first time, will cause low reproductive performance during their life.

\section{Service per Conception(S/C)}

Service per Conception is the number of AI services until a female becomes pregnant. From the results of the study, the $\mathrm{S} / \mathrm{C}$ value ranges from 1-3 times with an average of $1.56 \pm 0.55$. According to Toelihere
(1985), the normal S/C value for the territory of Indonesia is 1.602 .00 . The $\mathrm{S} / \mathrm{C}$ ratio in the research area in the SECP program is already very good. The lower the value of $\mathrm{S} / \mathrm{C}$, the higher the level of livestock fertility. The high value of S/C is caused by the delay of breeders and AI officers in detecting lust and the wrong time for AI. AI delay causes pregnancy failure. Evaluation of the efficiency of AI activities that is commonly carried out, namely $\mathrm{S} / \mathrm{C}$, the smaller the number, the goal of insemination biotechnology will be to achieve better reproductive efficiency which can affect the development of cattle populations in an area.

Factors that affect the high and low of pregnancy include the skills of the inseminator officers. The implementation of AI in the Kolaka area is carried out by inseminator officers who have long experience inseminating. In addition, inseminators in the research area have an insemination certificate and an Artificial Insemination Permit (SIMI), have PKB (Pregnancy Examination) expertise, this is in accordance with the Decree of the Minister of Agriculture which states that the technical implementation of $\mathrm{AI}$ in the field requires officers who have the skills something that is not easy for everyone to do. If the implementation of artificial isemination in the field is handed over to officers who have not or have not attended enough artificial isemination technical training, this is not allowed. in order to be able to perform artificial insemination, the inseminator must have a Permit to Perform Artificial Isemination (SIMI) issued by the agency in 
charge of animal husbandry and animal health functions in the local province.

The AI implementation is carried out after the farmer reports to the inseminator officer who will then come to the farmer to carry out AI. Susilawati (2011) adds that inseminator skills in AI techniques include thawing, cement deposition and artificial isemination timing. The thawing process is carried out with water and it is recommended that the temperature of the water be increased slowly to reduce the death rate of sperm cells because the effect on the thawing process is the same as during freezing.

The timing of artificial isemination is just before ovulation, that is, if the cattle shows signs of afternoon heat, the artificial isemination will be carried out in the morning the next day. The implementation of ai should not be carried out during the day because cervical mucus thickens during the day, while in the morning, afternoon and evening, cervical mucus becomes watery. This also has an impact on the success of artificial isemination during the day which is lower than in the morning, afternoon and evening. Spermatozoa are also very susceptartificial iseminationle to the heat of the sun so that the implementation of ai during the day is not profitable.

In addition to the human factor, livestock fertility is also very influential, females of exotic descent tend to have low fertility when in artificial isemination, but if they are bred naturally (using a squeezing male) it will be better. To get a uniform estrus at the desired time, estrus synchronization can be carried out. There are several methods of synchronization, ranging from the very simple to the use of hormones. The simplest synchronization method is by changing the pattern of exposure of livestock to light, because estrus in livestock is influenced by the length of the day. In addition, it can also be done by mixing males suddenly. Females are separated from males and then suddenly mixed with males, this can stimulate females to be in heat.

\section{Long pregnant}

In this study, the gestation period for bali cattle inseminated with brahman cattle semen was $9.03 \pm 0.38$ months. The duration of pregnancy is the period from the start of fertilization to the occurrence of normal birth (Jaenudeen and Hafez, 2000). The duration of pregnancy differs from one breed of livestock to another.

The duration of pregnancy is calculated from the distance between the implementation of artificial insemination (artificial isemination date) and the child's birth date. The duration of pregnancy is influenced by the type of cattle, sex and number of children conceived and other factors such as the age of the mother, season, genetic characteristics and geographic location (Jaenudeen and Hafez, 2000). Meanwhile, according to Astuti (1983), livestock genetic factors determine the capabilities of an animal, while environmental factors provide opportunities for livestock to display their abilities. This situation reflects that bali cattle have the ability to adapt to the environment quite well, as a result, their reproductive appearance does not differ from the area of origin. As stated by Pane (1991), bali cattle have good adaptability to new environments, both to temperature, air, humidity and wind, as well as to land conditions, feed, and disease.

\section{Calving Interval (CI)}

The Calving Interval in Bali cattle can be seen in Table 1. The results showed that the calving distance for Bali cattle was $12.24 \pm 0.52$ months. The Calving Interval in this study is in ideal conditions. The standard calving interval set by the Direktorat Jenderal Peternakan dan Kesehatan Hewan (2017) is 365 days. Meanwhile, the amount of CI is based on Ministerial Regulation No.19/Permentan/OT.140/2/2010 concerning 
General Guidelines for the 2014 Beef SelfSufficiency Program (PSDS), which is 15-21 months with an average of 17.5 months. Calving interval is one of the reproductive performance that needs to be known because the regularity of calving once a year guarantees the continuity of livestock production.

The ideal distance for calving in cattles is 12 months, which is 9 months of pregnancy and 3 months of lactation, but in reality the distance between calving and remarriage is generally long enough that the distance between cattle calving can be more than 12 months. If there is a long calving gap, it is mostly due to long birth and marriage intervals (days open). Rusdiana et al. (2018) stated that the calving interval is influenced by many factors including inseminator skills, livestock education, calf weaning age, S/C, postpartum marriage, and reproductive status.

\section{Birth Weight}

The results showed that the birth weight of calves from crosses between Bali cattle and Brahman males was $27.85 \pm 2.96 \mathrm{~kg}$. Birth weight is an important factor in the growth of calves. Cattles with a large birth weight and born normally will maintain their life better. Crossbreeding programs between local cattle and imported cattle can increase the birth weight of local cattle. The birth weight of Bali cattle is only in the range of 13$18 \mathrm{~kg}$ from Pane's (1990) study. Crossing local cattle (Bali) with imported cattle (Brahman) can improve the performance of the resulting chicks.

\section{Artificial isemination prime age correlation with birth weight}

The correlation between artificial isemination's first age and birth weight in this study was 0.77 . The correlation value of 0.77 indicates a very strong correlation between the first age of the cattle in ai and the birth weight of the cattle produced. A positive value indicates that the first age of artificial isemination and birth weight is in the same direction. This shows that the older the age of the cattle for mating, the greater the birth weight of the cattles produced. The age of cattle for the first time artificial isemination can be a reference for breeders to produce large birth weights.

\section{CONCLUSION}

Reproductive performance of Bali Cattle inseminated with Brahman Cattle Semen in SECP Program in Kolaka district include; first age artificial isemination $23.63 \pm 1.99$ months, service per conception (S/C) $1.56 \pm 0.55$ times, gestational age $9.03 \pm 0.38$ months, calving interval $12.24 \pm 0.52$ months, birth weight $27.85 \pm 2.96$ and the correlation between artificial isemination prime age and birth spacing was 0.77 .

\section{THANK-YOU NOTE}

Our gratitude goes to the Deputy for Strengthening Research and Development, Ministry of Research and Technology/National Research and Innovation Agency. Thank you to the Chancellor of the Ninebelas November Kolaka University and the Chair of the Research and Community Service Institute who have played a role in supporting the implementation of this research.

\section{REFERENCES}

Adawiyah, R.C., Rusdiana, S., \& Adianto, U. (2016). Peningkatan perekonomian melalui perbaikan produksi. Prosiding Seminar Nasional UGM Pasca Sarjana, 8 Oktober 2016, hal. 159-167.

Astuti, M.W., Hardjosubroto, Lebdosoekojo S. (1983). Analisis Jarak Beranak Sapi PO di Kecamatan Cangkringan 
DIY. Proceeding Pertemuan Ilmiah Ruminansia Besar. Bogor: Pusat Penelitian dan Pengembangan Peternakan BP3. Departemen Pertanian.

Badan Pusat Statistik Kabupaten Kolaka. (2020). Kabupaten Kolaka dalam Angka. Kolaka: Badan Pusat Statistik Kabupaten Kolaka.

Direktorat Jenderal Peternakan dan Kesehatan Hewan, Kementrian Pertanian. (2017). Pedoman Pelaksanaan Upaya Khusus Sapi Induk Wajib Bunting (UPSUS SIWAB 2017). hal. 1-21.

Gomez, A.A., \& Gomez, K.A. (2007). Prosedur Statistik untuk Penelitian Pertanian. Cetakan kedua. Jakarta: Universitas Indonesia.

Handiwirawan, E., \& Subandriyo. (2007). Potensi dan Keragaman Sumberdaya Genetik Sapi Baki. http://peternakan.litbang.deptan.go.id/d ownload/sapi/sapi04-9pdf

Jaenudeen, M.R., \& Hafez, E.E. (2000). Gestation, prenatal physiology and parturition. Di dalam: Hafez, E.S.E.E, \& Hafez, B., editor. Reproduction in farm animals. Ed ke 7. Philadelphia: Lippincott Williams dan Wilkins.

Lestariningsih, Aziz, R., \& Khopsoh, B. (2019). Pelatihan pengolahan tepung telur untuk meningkatkan pengetahuan kelompok PKK dan kelompok wanita tani Desa Jatinom Kanigoro Blitar. Briliant : Jurnal riset dan Konseptual, 4(1), 22-26.

Lindsay, D.R., Entwistle, K.W., \& Winantea, A. (1982). Reproduksi Ternak Di Indonesia. Malang: Fakultas Peternakan Universitas Brawijaya.

Pane, I. (1990). Upaya peningkatan mutu genetic sapi bali di P3. Bali Prosiding Seminar Nasional Sapi Bali. Bali. hal.20-22 September 1990.

Rusdiana, S., \& Soeharsono. (2018). Program SIWAB untuk meningkatkan populasi sapi potong dan nilai ekonomi usahan ternak. Forum Penelitian Agro Ekonomi. 35(2), 125-137.

Syakir, M. (2015). Dukungan teknologi peternakan dan veteriner dalam mewujudkan kedaulatan pangan hewani. Prosiding Seminar Nasional Teknologi Peternakan dan Veteriner.

Suryana, S., \& Munawar, K. (2017). Proses dan dinamika penyusunan undangundang No.18 Tahun 2012 tentang pangan. Forum Penelitian Agro Ekonomi, 35(1),1-17.

Susilawati, T. (2011). Spermatologi. Malang: UB Press.

Toelihere, M.R. (1985). Inseminasi Buatan pada Ternak. Bandung: Angkasa. 